\section{French inquiry into cancer charity focuses on "X."}

Last month, Nature Medicine reported that a public prosecutor in Paris had begun an investigation of Jacques Crozemarie, founder and chairman of the Association pour la Recerche sur le Cancer (ARC), France's largest medical charity. In fact, the prosecutor's preliminary investigation of the research charity is not focused on Crozemarie but on "X." According to French law, the person or persons involved in the alleged fraud at the ARC remain anonymous.

Meanwhile, since the publication in January of a report by a national audit commission showing not only that one-quarter of the charity's spending went to research but that financial irregularities may have occurred, ARC has been in turmoil. Crozemarie resigned on January 18 as Nature Medicine reported. Several days later ARC's executive board voted -17 voices against 11 - to replace him with Michel Lucas, a former head at the Inspection Generale des Affaires Sociales (IGAS), the government investigative agency on public bodies.

He led a 1990 investigation of ARC, initiated by the minister of health. Crozemarie blocked this investigation in administrative court, on the grounds that the IGAS had no legal right to investigate private charities. However, the key anomalies brought to light by Lucas' investigation have been confirmed by the national commission report.

Michel Lucas' appointment did not come as a complete surprise. A legal expert known for his integrity, and the author of the report revealing the French scandal concerning HIVcontaminated blood, Lucas, age 67 , appears to many, under present circumstances, to be the one person capable of restoring ARC's credibility. He has agreed to be its chairman for two months - time enough for him to restore order and stability. His first action was to freeze ARC's account and to require that all payments receive his personal approval.

\section{Catherine Tastemain} Paris, France

\title{
DID YOU KNOW?
}

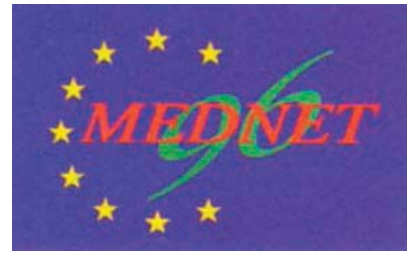

\section{Medicine on the Internet}

Brighton, United Kingdom, will play host to MEDNET 96, the European Congress of the Internet in Medicine on October 14-17, 1996. The Congress aims to bring together researchers, developers and users to explore where the Internet is exerting an influence on medicine and medical science. Tutorials, workshops and panel discussions will discuss access to information, clinical and nonclinical applications, electronic publishing and enhanced and virtual reality in medicine. Hosts of MEDNET 96 are the School of Cognitive and Computing Sciences and the Trafford Centre for Medical Research at the University of Sussex. Interested parties can gain more information about MEDNET 96 on the World Wide Web at http://www.mednet.org.uk/mednet/ mednet.htm.

\section{JENNIFER K. SNOW}

\section{French bishops approve condom use to prevent AIDS}

The French Bishops Conference recently announced that the use of condoms is necessary to prevent the spread of AIDS, according to a report by the Associated Press (2/13/1996). Their announcement contradicts Vatican doctrine against the use of condoms. The report, which reflects the policy of the Catholic Church of France, said that "many competent doctors affirm that a condom of good quality is currently the only method of prevention [of AIDS]. In that respect, it is necessary." While the French Bishops Conference and Pope John Paul II agree that abstinence outside marriage and fidelity within marriage are important morals to uphold, they disagree on how to prevent AIDS from spreading. The report strongly defends faithfulness in sexual relations but says that "the use of condoms is understandable in the case where sexual activity is already part of the person's behavior and there is a need to avoid a grave risk." The Vatican has yet to respond to the French report.

JENNIFER K. SNOW
UK geneticists join forces

Geneticists in the UK have joined forces to create a unified body from four separate societies. The British Society for Human Genetics wants to emulate its US counterpart in providing one focus representing the views of researchers, clinicians and counsellors.

This will give genetics a much stronger voice, with one organization representing the whole profession, said founding chairman Andrew Read, professor of Medical Genetics at St Mary's Hospital,

Manchester. "For example, there is much disquiet about the government's rejection of the proposed Human Genetics Commission (Nature Medicine 2, 139; 1996) but as four fragmented groups the opinion of geneticists carries less weight."

The initial membership of 1,250 comes from four separate groups: the Clinical Genetics Society, the Clinical Molecular Genetics Society, the Association of Clinical Cytogeneticists and the Association of Genetic Nurses and Counsellors.

The first chance for a get-together will be the new society's annual conference, which will be held at York University, September 15-18. Read hopes the amalgamation will give the conference the weight to pull in all the top research. "We want it to be like the US Society of Human Genetics annual meeting - a really good mix of researchers and people working in genetic services."

NuAla MORAN London

\section{Europeans promote public awareness of biotechnology} The European Commission is extending the program it set up in 1991 to advance public understanding of biotechnology, with a grant of $\$ 1.3$ million to fund a further three year's work. The money is going to the European Federation of Biotechnology, a pan-European organization incorporating more than 80 biotechnology-related scientific societies, including those involved in health care. The federation's Task Group on Public Perceptions of Biotechnology will use the funds to expand existing activities, including conferences, briefing papers and courses. A half-million dollars will be spent on a European public opinion survey that will be coordinated with similar research in the United States and Japan.

Nuala Moran London 